\title{
Is Estonian transit sector in trouble after the EU accession and sanctions against Russia? A qualitative study of transit flows
}

\author{
Viljar Veebel \\ Baltic Defense College, Tartu, \\ University of Tartu, Tartu, \\ Estonia \\ Viljar.veebel@,ut.ee \\ Raul Markus \\ Tallinn University of Technology, Tallinn, \\ Estonia \\ Raul@,optium.ee
}

Abstract. The article investigates the reasons why transit flows have been volatile in Estonia during 2000-2018. Based on academic literature, the authors identify the following potential factors: the effect of the EU accession, EU-Russian economic sanctions; changes in the transit volume of oil products; changes in local infrastructure in Estonia; dynamics of political and economic relations with Russia; changes in market demand and Estonia's inability to react and adjust to global trends; the development plan of Russian ports; dynamics of railway infrastructure charges in Estonia; unilateral nature of Estonia's transit flows; changes in competitiveness of the Estonian transit sector; changes in container transit in Estonia, and changes in the value added in the transit corridor of Estonia. To assess the impact of these factors, a qualitative survey was conducted among the companies operating in the Estonian transit sector and the local experts in transit-related issues. The survey shows that next to Russia's influence, other factors have also played a significant role. These are, e.g., the reorientation/restructuration of the Estonian transit sector, the impact of potential changes in local infrastructure, and the inability to identify long-term consequences of various policy measures imposed by its neighbours, or to estimate the outcome of other measures, such as the EU-Russian sanctions imposed during the Ukrainian conflict.

Keywords: Russia, European Union, Estonia, economic transit.

JEL Classification: F1, F5, P4 


\section{INTRODUCTION}

In principle, due to its favourable geographical location between Russia and the West, the economic transit transport should be one of the areas where the country should have permanent advantage. The reality, however, seems to be quite opposite, as the transit flows in Estonia have been extremely volatile. In the 1990s and early 2000s, economic transit by rail and through the ports which are both main transit channels in Estonia ${ }^{1}$ has steadily increased, but some time after Estonia's EU accession in 2004 the transit volumes have substantially decreased in Estonia and remain relatively low today.

This development could potentially be linked to Estonia's efforts to gradually change the focus of its partnership priorities after the collapse of the Soviet Union and to diminish contacts with Russia. However, such a development could also have much deeper causes, referring not only to changes in the country's priorities, but to other fundamental factors like changes in competitiveness environment, adjustments to global trends, political risks, and so on. The current article aims to provide an overview of the factors that could potential affect the Estonia's transit sector during 2000-2018, and to assess the importance of these factors from the perspective of local entrepreneurs and experts. A qualitative survey was conducted among Estonian companies operating in the economic transit sector and among the local policy experts. The dynamics of economic transit flows in Estonia has been investigated in several other studies, like Pukk (2011), Pukk et al. (2014), Tender and Kalmer (2014) or Lend et al. (2008); however, the current study differs from these studies in its systematic approach to all potential factors that could have affected Estonia's economic transit in various periods. Next to that, other studies do not include any qualitative surveys about the views of local entrepreneurs and policy analysts on that matter. Our qualitative survey which covered 16 companies operating in the Estonian transit sector, and 8 experts in the transit-related issues in Estonia is, in this respect, relatively unique.

Since the article also includes a comparison of the results of the qualitative survey and of other analytical studies in this field, the current study allows us to compare what academic researchers, entrepreneurs and policy analysts have to say about the factors that could potentially affect Estonia's economic transit over the last 20-30 years. Next to that, based on the views of local transit entrepreneurs and policy analysts, the current study also gives a glimpse at the outlook of the Estonian transit sector over the next decade.

The article is structured as follows. Section 1 identifies potential turning points in the Estonian transit sector, from 1996 to 2018. The dynamics of transit flows in Estonia will be discussed and potential factors behind the changes in transit volumes in Estonia in various periods will be highlighted. This basically constitutes the background of the qualitative survey. Section 2 describes the sample, the questionnaire and the methodology of the study. Section 3 introduces the results of the survey by summarizing the answers of Estonian entrepreneurs and policy analysts. Section 4 discusses the future outlook of the Estonia's transit sector. Section 5 concludes.

\section{TRENDS IN ECONOMIC TRANSIT IN ESTONIA IN 1990 -2018}

After Estonia has gained back its independence in the early 1990s, transit sector was highly important for the Estonian economy. The volumes of transit goods transported by rail and through the ports have steadily increased except a small setback in 2003 and a slight decrease in transit of goods by rail in 2005 (see Figure 1). At its peak in 2004, the share of the transit sector in the country's GDP reached over 10 percent

${ }^{1}$ In Estonia, economic transit takes place mostly in the multimodal transport chain, either in the form of ship-train or train-ship (Pukk, 2011). Other forms of transit transport, e.g., transit by cars or through airports, or combined transport chains like car and ship or train and car are only secondary options in Estonia (Devoino, 2017). 
(see Pukk et al. 2014). However, from 2005 on the growth in transit sector has turned to decline and stagnation, except a small improvement in transit flows in 2009-2010. Thus, based on the dynamics of the economic transit in Estonia three turning points in the Estonia's transit flows seem to occur:

- Year 2006 constitutes the peak and the first turning point in the Estonia's transit flows, after what the previously increasing trend started to invert to a decreasing trend;

- Year 2008 appears to be the second turning point, after what the downward trend reversed to a positive trend again;

- Year 2011 constitutes the third turning point, because after 2011 the situation in the Estonian transit sector worsened substantially and the transit volumes have basically not recovered since then. To illustrate it: the share of the transit sector in Estonia's GDP nowadays is a bit more than a half it was in mid-2000s (Pukk et al. 2014). However, recently in 2018, the volume of transit of goods by rail has to some extent increased again (Statistics Estonia 2019a).

Thus, in our survey the following periods are differentiated over the past two decades based on the dynamics of the transit flows in Estonia: 2000-2006, 2007-2008, 2009-2011, and a period from 2012 onward. The authors agree that last period (i.e. from 2012 on) might be too broad, considering the rapidly changing political and economic environment worldwide, however, the data on transit flows in Estonia do not indicate any systematic turns in this respect which means that there is also no need to further differentiate this period.

Having in mind the qualitative survey conducted in the framework of this study, it could be expected that until 2006 the overall assessment of the survey participants on the Estonian transit sector should be positive, and in 2007 and 2008 respectively negative. However, as the Estonian transit sector faced some setbacks already between 2000 and 2006, most likely some problems could be identified already during that period on the basis of the assessments of the survey respondents. This applies particularly to the assessments of the survey respondents operating in the railway sector, as in 2006 a fundamental shift occurred in the sense that transit volumes in ports started to exceed transit volumes by rail in Estonia. Considering a slight improvement in the Estonian transit sector in 2009-2011, it could be also expected that the assessments of local entrepreneurs and experts for this period potentially reflect some optimism, whereas from 2012 on their assessment on the transit environment in Estonia is most likely rather pessimistic.

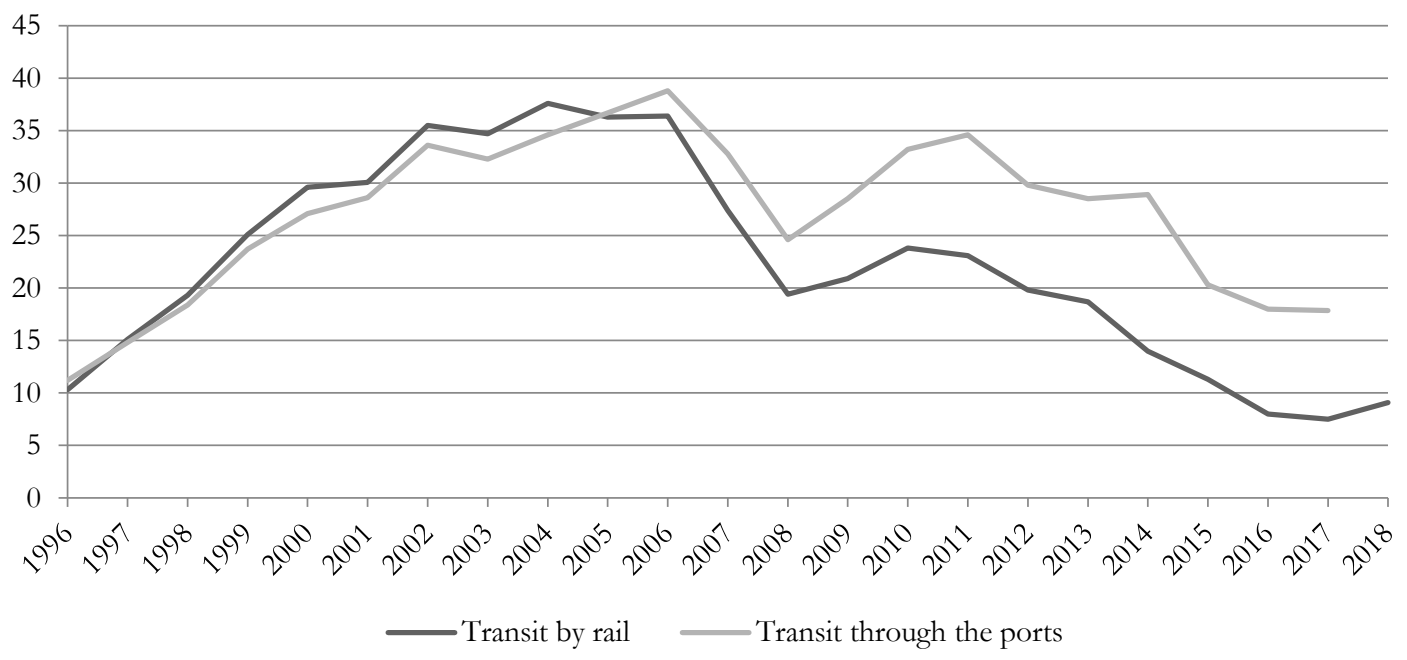

Figure 1. Dynamics of the transport of transit goods on rail and in ports in 1996-2018 (million tonnes)

Source: Statistics Estonia (2019a), Statistics Estonia (2019b). 
As far as the factors behind these changes are concerned, various reasons have been suggested in academic studies. The increase in transit volumes in early 2000s has been mainly associated with the rapid growth of transit of oil products, as Estonia used the typical model of the Baltic transit transport in which oil and petroleum products from Russia were transported to the ports of the Baltic Sea and loaded and shipped there (Saarniit, 2006; Pukk, 2011). Next to this, the opening of a modern coal terminal in Muuga Harbour in 2005 was assessed as a main positive factor (Saarniit, 2006).

The accession to the European Union in 2004 and the need to follow EU common market regulations started to have growing impact on Estonian transit flows from year 2004 on, as first the growth turned to stagnation in 2005 and decline from 2006 (Veebel \& Markus, 2018). However, next to that the drop in transit flows in 2007 and 2008 has also been associated with deterioration of international relations between Estonia and Russia and the decrease in market demand in 2008 (Pukk, 2011), Estonia's inability to react and adjust to global trends (Laidvee, 2008), and Russia's plan to reroute transit flows from ports the neighbouring countries to Russian ports by 2030 (Pukk et al., 2014). What makes this period particularly interesting to investigate in retrospect is the question of whether local entrepreneurs and experts had already then sensed the long-term difficulties and problems of the Estonian transit sector. The upward trend in transit flows in 2009-2010 has been mostly associated with the recovery of the demand both at ports and by rail (see Pukk, 2011).

The decrease in transit volumes of goods transported through Estonian ports and by rail after 2011 onward has been linked to many factors. It has been stated that decline in transit flows is the result of the development of Russian ports and the rerouting of cargo flows (Pukk et al., 2014). However, decline in transit flows from 2014 to 2018 has been also associated with the sanctions between EU and Russia caused by the Crimean annexation and ongoing conflict in Eastern-Ukraine. For example, Oja (2014a) argues that although the overall impact of the EU-Russian economic sanctions remains modest for Estonia, the local transit sector could be one out of two sectors, next to gas sector, which could seriously suffer from the deterioration of political relations between Russia and the EU. Simson (2017) assesses that the sanctions have negatively affected Estonia's economic growth between 2015 and 2016, particularly the transit sector, tourism, and industry in general.

Next to the external factors, experts have also pointed to more fundamental and long-term problems related to the local transit sector. Oja (2014b) stresses that for quite some time already the value added of the transit sector is decreasing, that this drop is by its nature structural and there is nothing to suggest that the transit volumes will recover in the coming years. Vare (2014) argues that several negative trends became visible already before the Ukrainian conflict erupted in 2013-2014. He also states that the attitude to transit is negative in Estonia, which also affects country's transit flows.

Furthermore, some politicians have argued that due to a missing national transit policy, a significant part of potential delivery capacities were transferred to Finland and Latvia (see Korb, 2016). This statement stems from a study by PricewaterhouseCoopers from 2014, stressing that based on the World Bank's logistics performance index, Estonia does not have significant qualitative advantages vis-à-vis Latvia and Finland, as far as the main logistics components such as customs, infrastructure, international shipments, logistics competence, tracking and tracing, and timeliness are concerned (Tender \& Kalmer, 2014). Another study of PricewaterhouseCoopers (2017) states that Estonia has lost trade volume while at the same time, its neighbouring countries have benefited from an increase in global trade volumes and that the competitiveness of Estonia as a transit corridor is relatively weak due to high prices (see Logistika et al., 2017).

Last but not least, some local entrepreneurs have strongly criticised Estonian politicians who supported stronger EU sanctions against Russia and suggested cutting political and economic relations with Russia to minimum (Vedler 2018). At the same time, other entrepreneurs take the view that Estonia should forget 
about the Russian transit flows because they are not recovering anyway and that new market niches in the Western countries should be found (Poverina, 2018).

In general, there is also a reference in the literature that the railway infrastructure charges (including waterway transport charges) in Estonia have increased significantly in 2006-2013, making Estonia's transit corridor more expensive than that of Latvia (Pukk et al., 2014). The role of the price increase of the Estonia's transit corridor in redirecting the trade flows to Latvia and Finland has been also stressed by another study (see Raudteeinfrastruktuuri, 2014). However it must also be noted that as most of transit flows originating from Russia depend on political will of Russian administration and the actual costs are only one part calculation, while political motives and preferences form the second one (Veebel \& Markus, 2016).

To sum up, all this leaves open the question of what factors have influenced the Estonian transit sector the most. Based on previous studies, the following potential factors behind the changes in the transit flows in Estonia over the last two decades are identified: the effect of European Union membership and EURussian economic sanctions; changes in the transit volume of oil products; changes in local infrastructure in Estonia; dynamics of political and economic relations with Russia; changes in market demand and Estonia's inability to react and adjust to global trends; the development plan of Russian ports; dynamics of railway infrastructure charges in Estonia; unilateral nature of Estonia's transit flows; and changes in competitiveness of the Estonian transit sector. However, the consultants of the survey also suggested including several additional factors in the survey, such as changes in container transit in Estonia, and changes in the value added in the transit corridor of Estonia.

Thus, in the following section the impact of all these factors will be assessed in a dynamic way over four period selected in the survey. Next to that, the survey offers an insight into the dynamics of the main transit partners of Estonia, assessed by local entrepreneurs and experts. This reveals another dimension of potential factors that could have an impact of the development of the Estonian transit sector. Most partner countries included in the survey were selected on the basis of statistical data provided by Statistics Estonia. These countries are Russia, Belarus, Kazakhstan, Ukraine, Uzbekistan, Turkmenistan, Latvia, Lithuania, and Tajikistan who are Estonia's main partner countries in rail transit and Russia and Finland as the main partner countries in transit through ports. Next to that, authors of the survey have included China and Sweden as countries with a significant potential in the future.

\section{METHODOLOGY AND DATA}

After the identification of potential factors that could affect the transit flows in Estonia over the last two decades, we conduct a qualitative survey to investigate the views and expectations of local entrepreneurs and experts in Estonia on this matter. To assess the results of the survey, we compare our results both with the results of other studies, as well as conduct two interviews with local experts to analyse and discuss the results of the survey.

The written survey consists of six broad questions, each of them having several sub-questions (the detailed survey questionnaire is available in Appendix 1). The questions are divided into two sections, focusing respectively on:

- The assessment of the situation in the transit sector in Estonia in various periods, the dynamics of factors that could potentially have an impact on transit flows in Estonia over the last two decades and on the changes in the structure of main transit partners for Estonia (Survey Section 1). Survey Section 1 covers both the whole period considered (i.e. 2000-2018) as well as differentiates between the subperiods defined on the basis on the turning points identified in section 1 of the current article (i.e. 20002006, 2007-2008, 2009-2011, and a period from 2012 onward). 
- The assessment of the outlook of the Estonian transit sector over the next decade and the estimated impact of various factors that could potentially influence Estonia's transit flows in the near future (Survey Section 2).

The most common rating scale in survey designs, the so-called Likert scale with scores $1-5$, was mostly used in the survey with 1 representing the negative end and 5 representing the positive end. The only exception is the question 6a(1) in Survey Section 2 with 1 representing the answer that the company definitely continues to operate in the transit sector in the future and 5 representing the answer that the company definitely does not continue to operate in the transit sector in the future. Next to this, multipleanswers or open-ended questions were used to identify the changes in the structure of Estonia's main transit partners (in both Survey Sections 1 and 2 the respondents were asked to list the main transit partners in various periods in the following way: the most important transit partner as 1, the second-important transit partner as 2, and the third-important transit partner as 3) and to assess the outlook of the Estonian transit sector over the next decade (respondents were asked to write answers to several questions in the Survey Section 2).

Throughout the survey, differentiation was made between entrepreneurs and experts in the sense that some questions are modified, depending on that whether entrepreneurs or experts are asked to answer the question. For example, whereas the entrepreneurs were asked about the main transit partners of their companies in corresponding periods, the experts were asked about the main transit partners of Estonia in corresponding periods. Where it appeared reasonable, differentiation was also made between transit of goods by rail and through ports.

The survey sample consists of 24 respondents, of which 16 respondents represent companies operating in the Estonian transit sector 2 and 8 respondents are experts in transit-related issues in Estonia. The companies included in the survey were mainly selected on the basis of the membership at the Estonian Logistics and Transit Association. The experts included in the survey were selected on the basis of their publications, presentations and research studies. The survey was conducted between February and May 2019. The results of the survey were collected and analysed in May 2019 and the first results of the survey were revealed in June 2019. The survey response rate was 58\%. However, the number of respondents to each question varies because of the modification of the questions with the aim to differentiate between the assessments of entrepreneurs and of experts.

\section{WHAT HAS AFFECTED THE ESTONIAN TRANSIT SECTOR IN 2008-2018 THE MOST? THE RESULTS OF QUALITATIVE SURVEY}

The overall trends in economic transit flows in Estonia in 2000-2018, as the entrepreneurs and experts seem them, are addressed by the survey questions No $1 \mathrm{a}, 1 \mathrm{~b}$ and $1 \mathrm{c}$. The results of our survey questions largely overlap with the main concern expressed in Estonia that the local transit sector has faced serious problems over the past two decades. All survey respondents have chosen only the scores "1" (referring to very problematic; 9 respondents) or " 2 " (referring to problematic; 3 respondents) to the question on the developments in the Estonia's transit sector between 2000 and 2018 and the dynamics in transit flows in general (i.e. survey question No 1a). As far as factors behind the changes in 2000-2018 are concerned, one definitely cannot get over of Russia: from the range of many options, all respondents marked either "EURussian economic sanctions" or "the dynamics of political and economic relations with Russia" with the

\footnotetext{
2 About $87 \%$ of the members of the Estonian Logistics and Transit Association were included in the survey.
} 
score 1, referring to the most negative impact of these factors on transit flows between 2000 and 2018 (see, Figure 2). This is particularly interesting, because the EU-Russian sanction could, at best, have a negative impact on the transit flows in Estonia only on the recent decade; however, in reality the sanctions were assessed to leave a negative trace to the Estonian transit sector during the whole period. Controversially, the impact of Russia's plan to reroute transit flows from the ports of the neighbouring countries to Russian ports by 2030 has not gained particularly negative feedback by the Estonian entrepreneurs and experts, and was basically assessed to have no impact (i.e. the assessment's score was 2.9 which is the closest to the category "no impact").

Next to Russia, in overall the survey results refer to problems linked with the unilateral nature of Estonia's transit flows, combined with the changes in the transit volume of oil products: according to the survey score, these factors were assessed to be more problematic than the others. At first sight, these answers could refer to more fundamental problems of the Estonian transit sector, however, at the same time the respondents have somewhat surprisingly disregarded changes in the overall competitiveness of the Estonia's transit sector and the changes in the value added in the Estonia's transit sector (i.e. the score of the survey for these factors was close to 3 , referring to the category "no impact"), although these factors could be interpreted as potential reflections of structural problems of the Estonian transit sector, too. Furthermore, the assessment that changes in competitiveness of the Estonian transit sector have not particularly affected the national transit sector negatively over the whole period observed is somewhat surprising in this light that according to the World Bank's Logistics Performance Index (LPI) for Estonia, which also indirectly refers to the overall competitiveness of the Estonian transit sector, the main components of LPI (e.g. infrastructure, international shipments, customs, logistics competence, timeliness, and tracking \& tracing) have gone through significant changes. For example, the scores of all main components reached its bottom in 2012, have increased in 2014 (in some cases the increase continued until 2016), but slightly decreased again in 2018 (World Bank 2019). It is unlikely that after dynamic changes in parameters and characteristics of the Estonian transit sectors, the overall competitiveness of the sector is basically estimated to remain unchanged. Next to that, in international comparison with the neighbouring countries and competitors in the area of transit, Estonia's LPI in 2018 is clearly lower than, for example, in Finland and Poland (Ibid.). Not surprisingly, Russia, Kazakhstan and Belarus were mentioned as the most popular transit partners of Estonia or of the Estonian companies between 2000 and 2018.

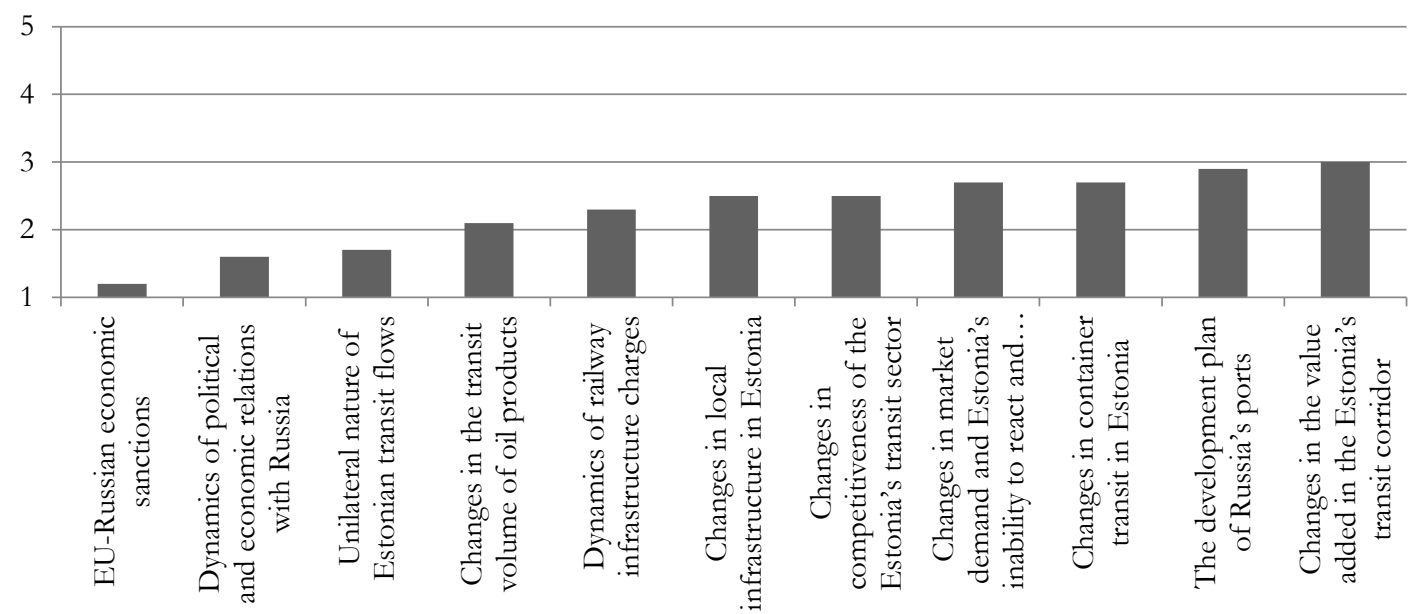

Figure 2. Answers to the survey question No 1b: "What is the impact of the following factors on the transit flows in Estonia between 2000 and 2018" (1 refers to significant negative impact, 3 to no impact, and 5 to significant positive impact) 
The survey questions No $2-5$ continue to examine potential factors behind the changes in the transit flows in Estonia. Thus, first, differentiation is made between four sub-periods: 2000-2006, 2007-2008, 2009-2011, and a period from 2012 onward. Next to that, differentiation is made also between the state of the Estonia's transit sector in overall, and the situation of a particular enterprise or a company in selected periods (see questions 2a and 2a(1); $3 a$ and $3 a(1) ; 4 a$ and $4 a(1)$, and $5 a$ and $5 a(1)$ ). Again, the score 1 refers to "very problematic", 3 to "moderate concerns", and 5 to "no problems at all". These results of these survey questions are highlighted in Figure 3.

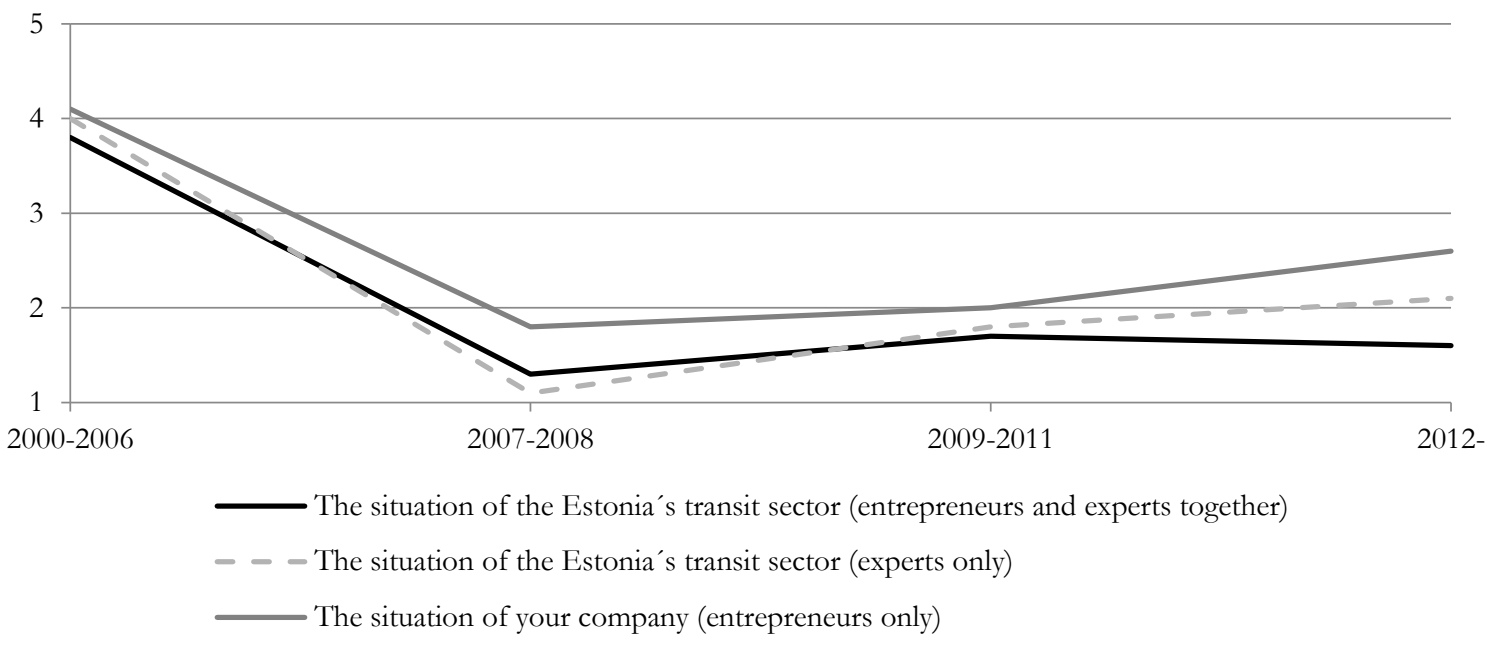

Figure 3. Answers to the survey questions $2 \mathrm{a}$ and $2 \mathrm{a}(1) ; 3 \mathrm{a}$ and $3 \mathrm{a}(1) ; 4 \mathrm{a}$ and $4 \mathrm{a}(1)$, and $5 \mathrm{a}$ and $5 a(1)$ : "What was the state of transit sector in Estonia/your company respectively in..." (1 refers to "very problematic", 3 to "moderate concerns", and 5 to "no problems at all")

Figure 3 indicates that the respondents' assessments on the developments in the Estonian transit sector and on the situation of particular company linked to the transit sector in Estonia go basically hand in hand, except the last period observed (i.e. from 2012 on). The survey respondents suggest that there were no particular problems in the early 2000s, but from 2007 on the Estonian transit sector faced already significant problems according to their assessment, and the situation has not significantly improved during the shorttime recovery period in 2009-2011 (the closer is the score to 1, the more problematic the factor is assessed to be). Somewhat surprisingly, those experts who have participated in the survey seem to be more pessimistic about the state of the sector in 2007-2008 in comparison with the entrepreneurs, but more optimistic about the recent development from 2012 onwards in the local transit sector. However, at the same time the entrepreneurs assess that, specifically, the situation of their own companies has gradually improved and the problems have decreased over time (again the closer is the score to 1 , the more problematic the factor is assessed to be).

In order to have better overview of the assessments on the dynamics of various factors, as a next step those factors are divided into three categories:

First, factors related to Russia, referring to EU-Russian economic sanctions, the dynamics of political and economic relations with Russia, changes in the transit volume of oil products, and Russia's plan to reroute transit flows from the ports of the neighbouring countries to Russian ports (see Figure 3(a)).

Second, factors that could be classified as fundamental (or even structural) changes in the Estonian transit sector, such as changes in the unilateral nature of Estonia's transit flows, changes in competitiveness of the Estonian transit sector, changes in market demand and Estonia's inability to react and adjust to global trends, and changes in the value added in the Estonia's transit corridor (Figure 3(b)). 
Third, factors that associate with more sector-specific and detailed topics, like dynamics of railway infrastructure charges, changes in local infrastructure in Estonia, and changes in container transit in Estonia (Figure 3(c)).

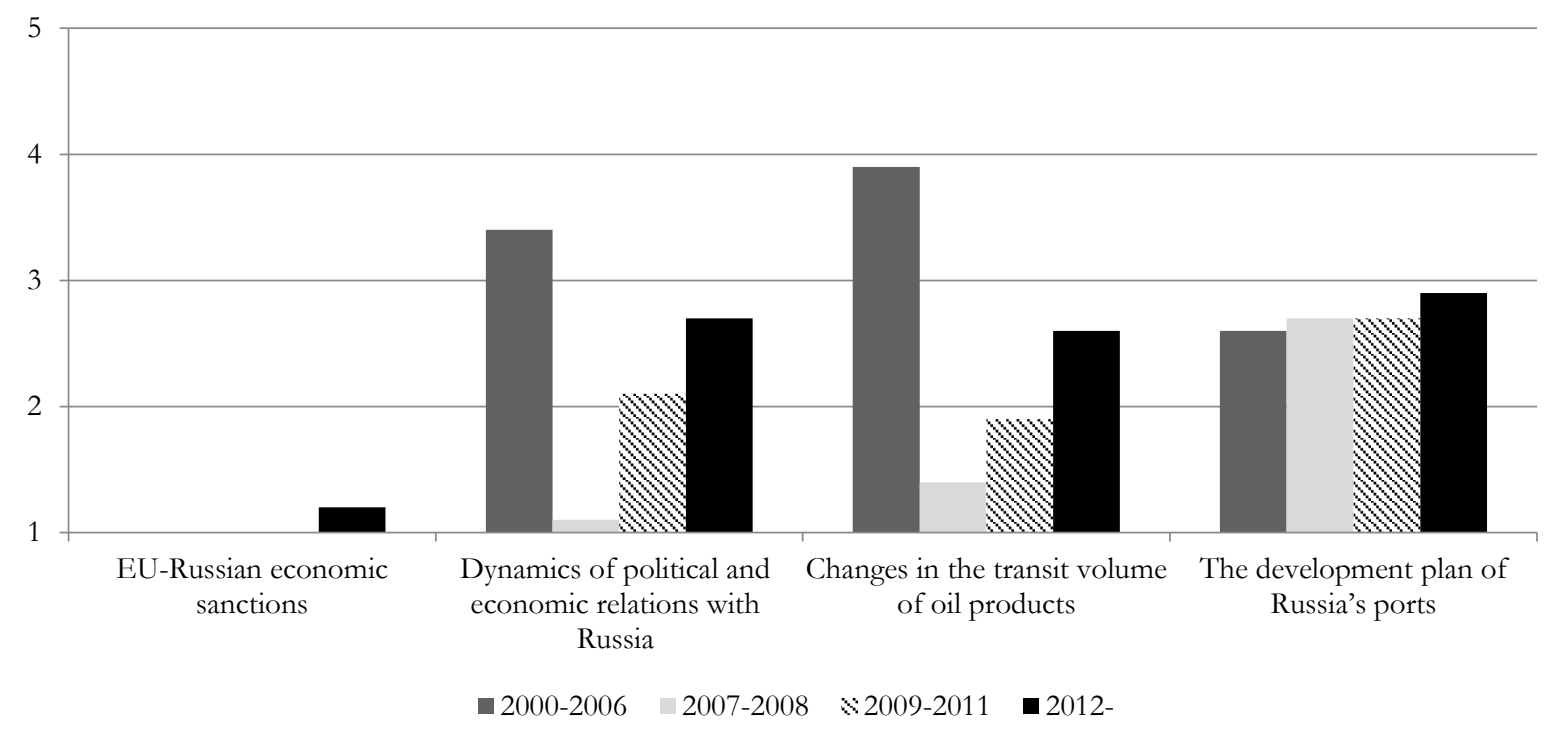

Figure 3(a). Answers to the survey questions $2 a$ and 2a(1); $3 a$ and $3 a(1) ; 4 a$ and $4 a(1)$, and $5 a$ and $5 a(1)$ : Factors related to Russia (1 refers to strong negative impact, 3 to no impact, and 5 to strong positive impact)

In this light, the overall picture definitely becomes more varied. Figure 3(a) indicates that from 20072008 on, the negative impact of most topics related to Russia seems to decrease over time and to become less and less significant in each subsequent period. Of course, this does not apply to the negative impact of the EU-Russian sanctions, because there is no reference period as well as today there is not much hope to expect that something will change in the nearest future. However, as already mentioned, other topics related to Russia seem to increasingly less affect the transit sector in Estonia, based on the assessments of Estonian entrepreneurs and experts. The roots of such an assessment are difficult to identify only on the basis of the survey. For example, this may controversially indicate that either the Estonian transit sector is currently undergoing some reorientation from Russia to other partners and is, therefore, not so vulnerable anymore as far as Russia is concerned, or that the Estonian entrepreneurs and experts are finally accepting the fact that Russian market is lost for the Estonian transit anyway, and they do not assess the impact of Russianrelated issues so negatively anymore. Therefore, this question definitely needs to be investigated further.

Next to that, our survey results confirm the previous statement that the impact of Russia's plan to reroute transit flows from the ports of the neighbouring countries to Russian ports by 2030 is assessed to be not so important, based on the views of Estonian entrepreneurs and experts. Only one respondent constantly scored this factor as having significant negative impact on the Estonian transit sector. 


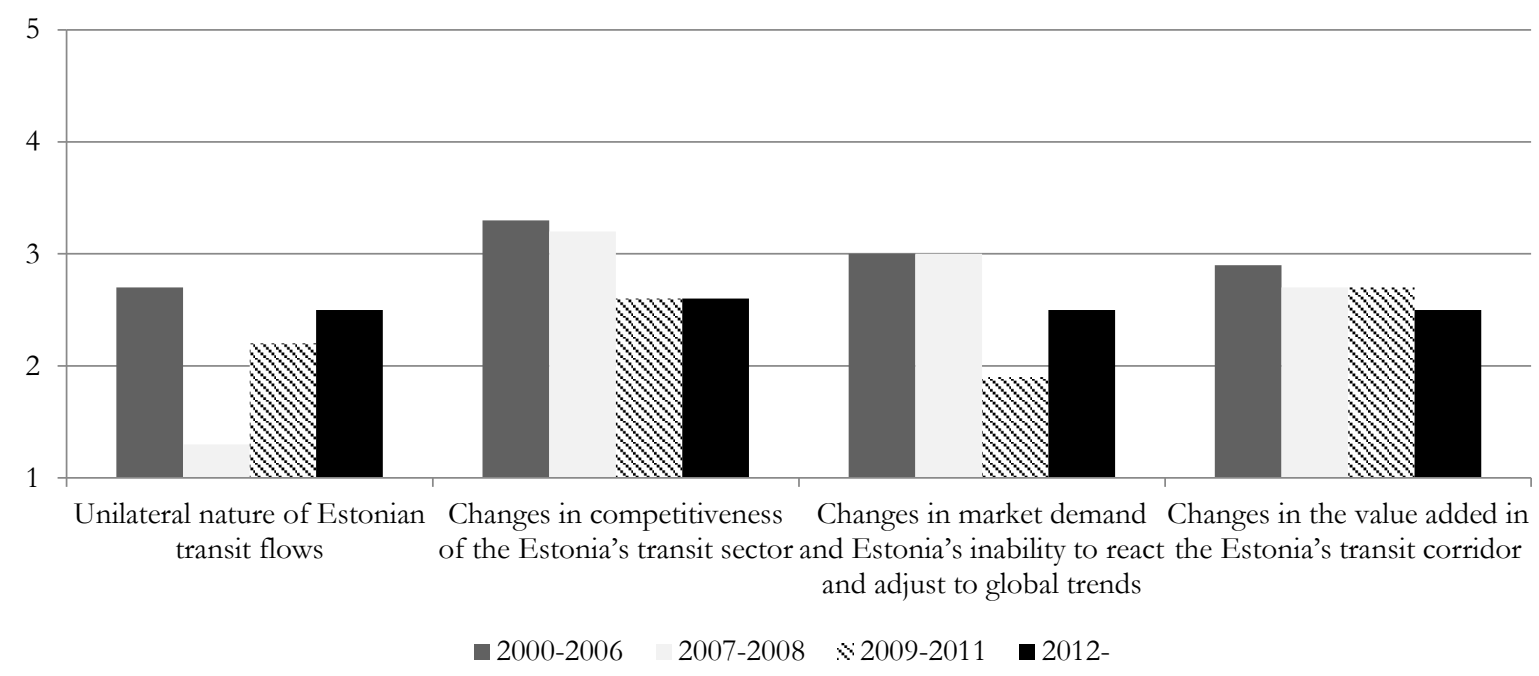

Figure 3(b). Answers to the survey questions $2 \mathrm{a}$ and $2 \mathrm{a}(1)$; $3 \mathrm{a}$ and $3 \mathrm{a}(1) ; 4 \mathrm{a}$ and $4 \mathrm{a}(1)$, and $5 \mathrm{a}$ and $5 a(1)$ : Factors linked to general trends and conditions of the Estonia's transit sector (1 refers to significant negative impact, 3 to no impact, and 5 to significant positive impact)

The dynamics of our survey assessments on factors that could be classified as fundamental (or even structural) changes in the Estonian transit sector in various periods over the past two decades also reveal some thought-provoking results. On the one hand, Figure 3(b) indicates that the changes in competitiveness of the local transit sector is assessed to cause more and more problems over time from 2007 on, and the same applies to changes in the value added in the Estonia's transit corridor. The unilateral nature of the Estonian transit flows, which was estimated to have a relatively negative impact on the Estonian transit sector in overall, is assessed not to be problematic anymore from 2007-2008 on.

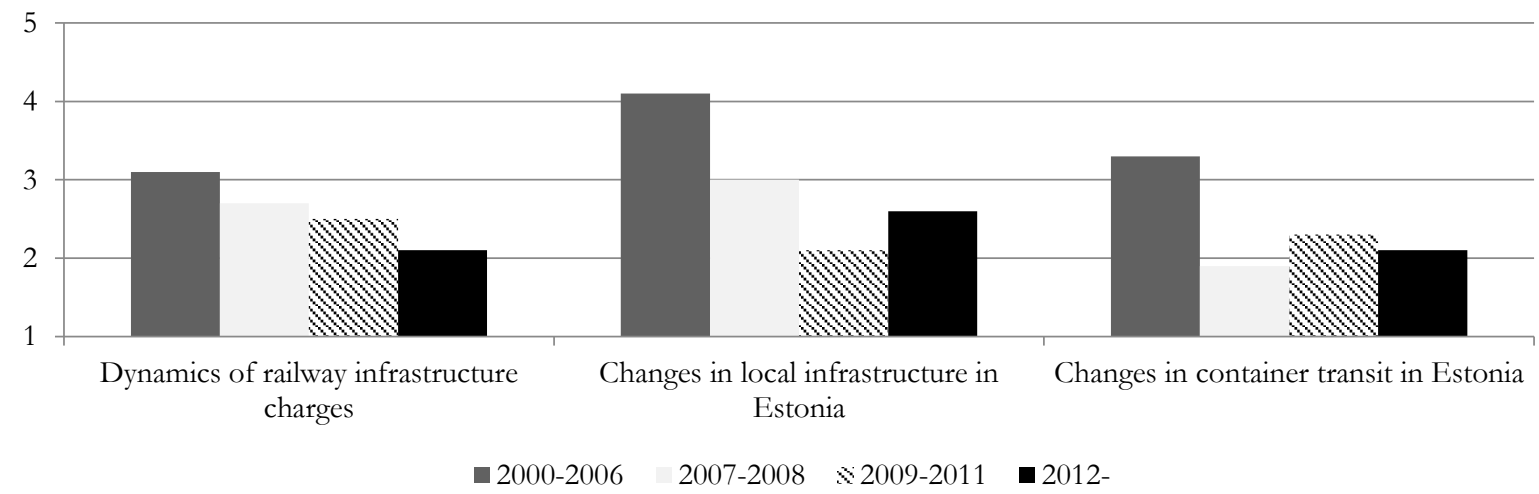

Figure 3(c). Answers to the survey questions $2 a$ and 2a(1); $3 a$ and 3a(1); $4 a$ and 4a(1), and 5a and $5 a(1)$ : Factors linked to more detailed topics of the Estonia's transit sector ( 1 refers to significant negative impact, 3 to no impact, and 5 to significant positive impact)

This confirms that some reorientation and restructuration is taking place in the Estonian transit sector. Problems related to the changes in the global market demand and Estonia's inability to react and adjust to these global trends have been highlighted particularly for the period 2009-2011, which seems to be justified in the context of the recovery from the recent global financial crisis. By the way, one survey respondent also directly mentioned negative impact of the global financial crisis on the Estonian transit sector during this period. Among the factors that associate with more sector-specific or detailed topics such as dynamics of 
railway infrastructure charges, changes in local infrastructure in Estonia, and changes in container transit in Estonia, the negative impact of the dynamics of railway infrastructure charges seems to concern the Estonian entrepreneurs and experts more and more (see Figure 3(c)). The impact of changes in the local infrastructure over various periods of time seems to concern the survey respondents the least, however, this factor could be somewhat underestimated by the survey respondents, because logistical infrastructure constitutes "the lifeblood of the economy", as one high-level expert in Estonia has rightly observed.

At the first glance, further results of the survey oppose the idea of transit reorientation taking place in Estonia in this respect that based on the survey results Russia is assessed to be the main transit partner of Estonia/of Estonian companies during the whole period (in most cases ranked as No 1 in the questions 2c, $3 c, 4 c$ and $5 c)$. However, again what may to some extent dismiss the argument is that in latter periods the range of countries that have been mentioned as main transit partners of Estonia has somewhat widened, covering not only Russia, Belarus and Kazakhstan, but also, Finland, Sweden, Latvia and Lithuania.

To sum up, first, the survey results to some extent support the idea of the reorientation or restructuration of the Estonian transit sector, referring both to the assessment that negative impact of most factors related to Russia's behaviour seems to be less and less significant in each subsequent period, and that potential diversification of the transit partners of Estonia has taken place over time. Second, the fact that simultaneously the EU-Russian sanctions were assessed to have strong negative effect on the Estonian transit sector in 2000-2018, but Russia's plan to reroute transit from the ports of the neighbouring countries to Russian ports was assessed rather not to have an impact on the transit in Estonia could refer to a more challenging problem of being able to identify long-term consequences of various policy measures. In its essence, the long-term consequences of the latter could be as dangerous as of the former; however, this risk is not fully recognized by the respondents. Last but not least, the impact of potential changes in the local infrastructure should not be underestimated. Constant and systematic development of the network of roads, ports, railways, airports and so on, constitutes a necessary precondition for stable and transit-friendly economic environment.

\section{WHAT ABOUT THE FUTURE? THE OUTLOOK FOR THE ESTONIAN TRANSIT SECTOR FOR 2020-2029}

The second part of the survey is aimed to estimate the outlook of the Estonian transit sector over the next decade. Again, the survey respondents were asked to assess the overall state of the Estonian transit sector between 2019 and 2029, as well as to evaluate the factors that could potentially have an impact on transit flows in Estonia over the next decade.

In overall, the Estonian transit entrepreneurs and experts seem to remain pessimistic about the outlook for the Estonian transit sector. Again, all survey respondents have chosen only the scores "1" ("very problematic) or "2" ("problematic"), however, this time majority of the respondents selected the score "2" to the survey question No 6a. At the same time, six out of 8 entrepreneurs assessed that they are highly likely operating in the transit sector also in 2019-2029, and two companies couldn't answer the question (see the survey question $6 \mathrm{a}(1)$ ). This may indicate that the survey respondents are actually not so pessimistic about the outlook of the Estonian transit sector anymore over the next decade as it may appear at the first glance, and that despite some problems the Estonian companies and experts still see the potential of the national transit sector.

As far as the assessment of factors behind potential changes in 2019-2029 is concerned (see survey question No 6b), most of the factors are expected to have slightly more negative impact on the Estonian transit sector in the near future in comparison with the period of 2012-2018, except the negative impact of the EU-Russian sanctions is expected to decrease, and the neutral or slightly negative impact of the changes 
in the local infrastructure is expected to turn to a positive one, most likely because of the expected Rail Baltic project (see Figure 4). The latter overlaps with the Rail Baltic Global Project Cost-Benefit Analysis, arguing that Rail Baltic should improve the freight shipment potential by rail both for the import/export traffic of the Baltic countries as well as transit traffic in the region, referring mainly to trade of Finland and Poland with other countries in the Nordic-Baltic region. Based on the report, the improvement is expected to occur particularly from the removal of break-of-gauge barrier on the border of Poland and Lithuania, and from the established intermodal logistics terminals in Muuga, Salaspils, Kaunas and Vilnius (Rail Baltica..., 2017).

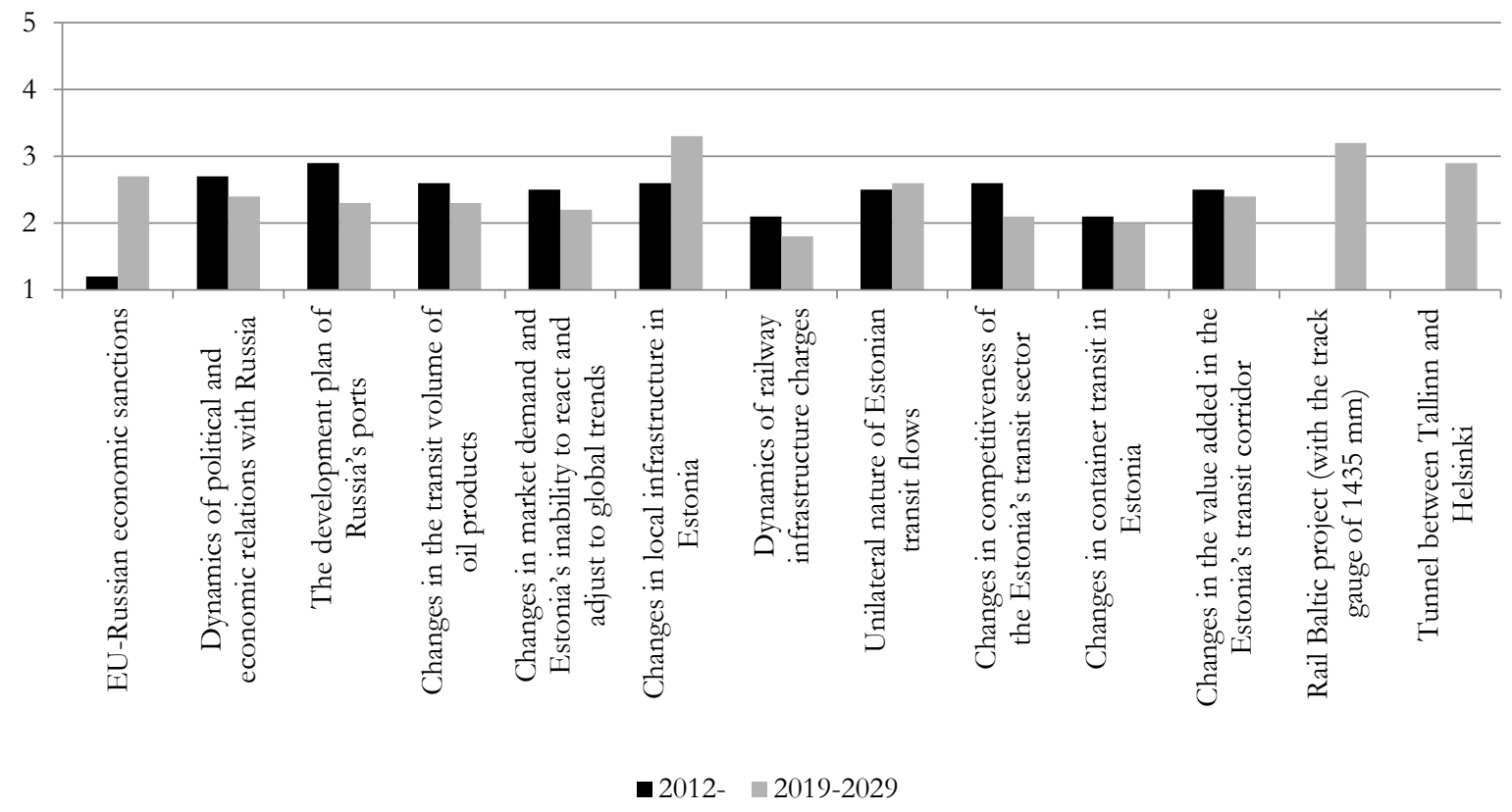

Figure 4. Answers to the survey questions No 5b and 6b: "What is the impact of the following factors on the transit flows in Estonia..." (1 refers to strong negative impact, 3 to no impact, and 5 to strong positive impact)

Over the next decade, the range of the partner countries is assessed to somewhat increase according to the survey, as some "new" countries with a huge potential have been named in the survey, such as China. This is, in principle, in accordance with the view that the negative impact of the unilateral nature of the Estonian transit sector on the sectoral development is also expected to decrease in 2019-2029, as indicated in Figure 4 (the farther is the score of 1, the less problematic the factor is assessed to be).

At the end of the questionnaire, the respondents were asked to assess the potential transit volumes in the Estonian transit sector in the future and to share their view of what needs to be done (or what should not be done) to improve the state of the Estonian transit sector, including their recommendation about the policy measures (see the questions $6 \mathrm{~d}, 6 \mathrm{e}$, and $6 \mathrm{f}$ ).

One policy recommendation concerned the revision of the EU-sanctions, and two other policy recommendations were suggesting to strengthen cooperation between the government and the entrepreneurs operating in the Estonian transit sector, or to consider tax cuts for the companies operating in the logistics and transit sector.

Most of the experts agreed that competition within the Baltic region over the transit flows is intense, an in this respect any efforts to gain advantages for Estonia must be highly valued. However, it was stressed the need to have a broader and more balanced view in this matter. The biggest challenge for the Estonian transit sector in the near future is the short-sighted attitude toward the development of local infrastructure 
as logistical infrastructure constitutes "the lifeblood of the economy", as already mentioned, and unfortunately rail transport has across time remained in the background in Estonia, as far as investments in rail transport are concerned. The EU funds have contributed to the improvement of local infrastructure in Estonia, however, this does cannot last forever, and compared to, for example Poland or Ireland, Estonia has not paid much attention to the improvement of the local infrastructure.

In this context, experts have also stressed the importance of the Rail Baltic project to the recovery of the transit flows in Estonia. Since the project is not focused on transit flows from Russia but from Finland and Poland, its potential for increasing transit flows is significant for Estonia. Last but not least, experts were pessimistic about the recovery of the transit flows between Russia and Estonia in the future, and have welcomed the trend to focus on other markets. In this respect, also the potential of other forms of transit transport like transit goods flow passing through Estonia through the airports should not be underestimated. In this context, Estonia should act like Japan who has ignored its huge and resource-rich neighbour, China, and has diverted its economic interests to strong and more stable markets.

\section{CONCLUSION}

The current study investigates the factors behind the changes in the transit flows in Estonia over the last two decades and estimates the future outlook of the Estonian transit sector. The study is by large based on a qualitative survey on the expectations and views of local entrepreneurs and experts in Estonia conducted in the first half of 2019. The survey basically confirms the main concern expressed in Estonia that the local transit sector has faced serious problems over the past two decades. However, research results offer are diversified: on the one hand, the survey assessments have shown that local entrepreneurs and experts consider Russia partially responsible for this. On the other hand, when assessing the impact of various factors on the state of the Estonian transit sector in various periods (i.e. 2000-2006, 2007-2008, 2009-2011, and a period from 2012 onward), the results of the survey allow drawing some interesting conclusions. First, the reorientation or restructuration of the Estonian transit sector (referring to the assessment that negative impact of most factors related to Russia's behaviour seems to be less and less significant in each subsequent period, and that potential diversification of the transit partners of Estonia has taken place over time) seems to take place which is a good news for the country, considering the fact that until now Russia has been an extremely unstable transit partner for Estonia. Second, unfortunately the impact of potential changes in the local infrastructure might be somewhat underestimated in Estonia until now, since the country has not constantly and systematically developed the network of roads, ports, railways, airports and so on. Today, this could seriously backfire Estonia when country attempts to and restructure and re-orientate its transit sector. Third, the Estonian transit sector might face a challenging problem of being able to identify long-term consequences of various policy measures, for example, the consequences of Russia's plan to reroute transit from the ports of the neighbouring countries to Russian ports, or overestimate the outcome of other measures, such as the EU-Russian sanctions imposed during the Ukrainian conflict.

In the future, one of the biggest challenges for the Estonian transit sector seems to be the short-sighted attitude toward the development of local infrastructure. Until now, Estonia has not paid much attention to the systematic improvement of the local infrastructure, but should do that soon. The Rail Baltic project could contribute to the recovery of the transit flows in Estonia, because it is not focused on transit flows from Russia but from Finland and Poland.

\section{ACKNOWLEDGEMENT}

Authors have not received any support or funds to carry out this research. 


\section{REFERENCES}

Devoino, J. (2017). Konteinervedude transïdi viimased muntused ja selle mõjud ettevõtte iLogistics näitel. Tallinna Tehnikaülikool. https://digi.lib.ttu.ee/i/?8520

Korb, M. (2016). Mihhail Korb: tänase poliitikaga jätkatespundub Eesti randteesektoril tulevik. Pealinn, published on 8 February 2016. http://www.pealinn.ee/newset/mihhail-korb-tanase-poliitikaga-jatkates-puudub-eesti-n162440

Laidvee, E. (2008). Transiit ei käi ajaga kaasas?. Eesti Päevaleht, published on 13 June 2008. http:/ / epl.delfi.ee/news/arvamus/erik-laidvee-transiit-ei-kai-ajaga-kaasas?id=51133019

Lend, E., Eidast, A., Segercrants, W., Uustalu, A.-M., \& Uriko, M. (2008). Eesti transiit ja logistika: tänapäev ja tulevik. Uuringu II osa aruanne. Tallinn, 2008. https://www.riigikogu.ee/wpcms/wpcontent/uploads/2014/11/Eesti_transiit_ja_logistika_II_osa.pdf

Logistika ja Transiidi Assotsiatsioon. (2017). Estonian Clusters: Valminud on uuring „Eesti Logistikasektori majandusmõju ja rahvusvabeline konkurentsivoime“. Published on 1 March 2017. https://www.estonianclusters.ee/valminud-onuuring-eesti-logistikasektori-majandusmoju-ja-rahvusvaheline-konkurentsivoime/

Logistikadoktor: Vene transiit ei taastu kunagi. Logistikauudised (www.logistikauudised.ee), published on 30 April 2018. http://www.logistikauudised.ee/uudised/2018/04/30/logistikadoktor-vene-transiit-ei-taastu-kunagi

Oja, K. (2014a). Ökonomist: Vene sanktsioonide möju Eesti majandusele jääb 0,3 protsendi piiresse. ERR (Estonian Public Briadcasting), published on 11 September 2014. https://www.err.ee/519868/okonomist-vene-sanktsioonidemoju-eesti-majandusele published on 11 September 2014. Available in Estonian only -jaab-0-3-protsendipiiresse

Oja, K. (2014b). Kaspar Oja: majanduslangus - mis saab edasi? Postimees, published on 19 May 2014. https:/ / arvamus.postimees.ee/2798822/kaspar-oja-majanduslangus-mis-saab-edasi

Rail Baltica Global Project Cost-Benefit Analysis. (2017). EY/Co-financed by the European Union. http://www.railbaltica.org/cost-benefit-analysis/

Raudteeinfrastruktuuri kasutustasude analüüs. (2014). Uuring Logistika ja Transiidi Assotsiatsiooni tellimisel. Final version, published on 12 May 2014 (available in Estonian only). PwC.

Saarniit, A. (2006). Kui suur on transiidiäri osatäbtsus Eesti majanduses? Kroon ja majandus, 1/2006. https://www.eestipank.ee/sites/default/files/publication/et/Arhiiv/kroon_majandus/2006/_6.pdf

Simson, U. (2017). Eesti makromajandus. Presentation by Swedbank in March 2017 (available in Estonian only). https://www.slideshare.net/SwedbankEestis/eesti-makromajandus-2017

Tender, T., \& Kalmer, K. (2014). Logistikasektori mõjuulatus Eesti majanduses. PwC uuring Logistika ja Transiidi Assotsiatsiooni tellimusel, published on 16 June 2014. www.portoftallinn.com/? $\mathrm{dl}=612$

Transiit Eesti raudteel kogub jõudu. (2018). Äripäev, published on 12 June 2018 (available in Estonian only). https://www.aripaev.ee/uudised/2018/06/12/transiit-eesti-raudteel-kogub-joudu

Vare, R. (2014). Transiidi- ja transpordiliikluse tulevikust: Eesti võimalused. Presentation at the conference „TTK 50 konverents" on 1 April 2014 (available in http://www.teed.ee/uploads/ckeditor/files/2\%20RV_Transiidi$\% 20 \mathrm{ja} \% 20$ transpordiliikluse $\% 20$ tulevikust_fin.pdf

Vedler, S. (2018). Tït Vähi ja Enn Veskimägi: venevaenulikkus on absoluutselt vale liin. Eesti Ekspress, published on 27 April 2018 (available in Estonian only). https://ekspress.delfi.ee/erid/tiit-vahi-ja-enn-veskimagivenevaenulikkus-on-absoluutselt-vale-liin?id=81494421

Veebel, V. (2017). Russia's Neo-Imperial dependence model: Experiences of former Soviet republics. Romanian Journal of Political Sciences, 17(1), 4-34.

Veebel, V., \& Markus, R. (2016). At the dawn of a new era of sanctions: Russian-Ukrainian crisis and sanctions. Orbis, 60(1), 128-139. 
Veebel, V., Markus, R. (2018). The bust, the boom and the sanctions in mutual trade relations with Russia. Journal of International Studies, 11(1), 9-20.

Veebel, V., Ploom, I., \& Markus, R. (2018). EU-Financed Peripheral Large-Scale Infrastructure Projects and the White Elephant Syndrome: the Example of Rail Baltica. Romanian Journal of European Affairs, 18(1), 113-128.

World Bank (2019). The World Bank's Logistics Performance Index (LPI). https://lpi.worldbank.org/international/scorecard/column/254/C/EST/2018/C/EST/2016/C/EST/2014 /C/EST/2012/C/EST/2010/C/EST/2007\#chartarea 


\section{APPENDIX 1}

The survey questionnaire

Part I of the survey: Your assessment of the state of transit flows in Estonia, the problems Estonian transit sector is facing and the main transit partners of Estonia

1a: What was the state of transit sector and the transit flows in Estonia in 2000 - 2018 altogether?

\begin{tabular}{|c|c|c|c|c|}
\hline Very problematic & & Moderate concerns & & No problems at all \\
\hline 1 & 2 & 3 & 4 & 5 \\
\hline
\end{tabular}

1b: What is the impact of the following factors on the transit flows in Estonia between 2000 and 2018.

\begin{tabular}{|c|c|c|c|c|c|}
\hline & $\begin{array}{c}\text { „1“6 } \\
\text { Strong } \\
\text { negative }\end{array}$ & $\begin{array}{c}\text { „2“ } \\
\text { Moderate } \\
\text { negative }\end{array}$ & $\begin{array}{c}, 3^{\prime \prime} \\
\text { No } \\
\text { impact }\end{array}$ & $\begin{array}{c}\text { „4“" } \\
\text { Moderate } \\
\text { positive }\end{array}$ & $\begin{array}{c}\text {,5“6 } \\
\text { Strong } \\
\text { positive }\end{array}$ \\
\hline \multicolumn{6}{|l|}{ The EU-Russian economic sanctions } \\
\hline \multicolumn{6}{|l|}{ Political and economic relations with Russia } \\
\hline \multicolumn{6}{|l|}{ The development plan of Russian ports } \\
\hline \multicolumn{6}{|l|}{ Changes of transit volume of oil products } \\
\hline \multicolumn{6}{|l|}{ Estonia's inability to adjust to global trends } \\
\hline \multicolumn{6}{|l|}{ Changes in local infrastructure in Estonia } \\
\hline \multicolumn{6}{|l|}{ Dynamics of railway infrastructure charges } \\
\hline \multicolumn{6}{|l|}{ Unilateral nature of Estonia's transit flow } \\
\hline \multicolumn{6}{|l|}{ Competitiveness changes of Estonian transit sector } \\
\hline \multicolumn{6}{|l|}{ Changes in container transit in Estonia } \\
\hline Changes in the value, added in the transit corridor & & & & & \\
\hline
\end{tabular}

1c: Entrepreneurs to respond to the question: Who are 3 main transit partners of your company during the whole period 2000-2018 investigated? Experts to respond to the question: Which countries were 3 main transit partners of Estonia during the whole period 2000-2018 investigated?

$2 \mathrm{a} / 3 \mathrm{a} / 4 \mathrm{a} / 5 \mathrm{a}$ : What was the state of transit sector and the transit flows in Estonia in 2000-2006/in 2007-2008/in 2009-2011/from 2012 on?

\begin{tabular}{|c|c|c|c|c|}
\hline Very problematic & & Moderate concerns & & No problems at all \\
\hline 1 & 2 & 3 & 4 & 5 \\
\hline
\end{tabular}

$2 a(1) / 3 a(1) / 4 a(1) / 5 a(1)$ : How would you characterise the state and wellbeing of your company and the dynamics of the transit flows of your company in the Estonian transit sector in 2000-2006/in 2007-2008/in 2009-2011/from 2012 on?

\begin{tabular}{|c|c|c|c|c|}
\hline Very problematic & & Moderate concerns & & No problems at all \\
\hline 1 & 2 & 3 & 4 & 5 \\
\hline
\end{tabular}

$2 \mathrm{~b} / 3 \mathrm{~b} / 4 \mathrm{~b} / 5 \mathrm{~b}$ : What is the impact of the following factors on the transit flows in Estonia in 2000-2006/in 20072008/in 2009-2011/from 2012 on.

\begin{tabular}{|l|c|c|c|c|c|}
\hline & $\begin{array}{c}\text { "1“ } \\
\text { Strong } \\
\text { negative }\end{array}$ & $\begin{array}{c}\text { Moderate } \\
\text { negative }\end{array}$ & $\begin{array}{c}\text { No } \\
\text { impact }\end{array}$ & $\begin{array}{c}\text { Moderate } \\
\text { positive }\end{array}$ & $\begin{array}{c}\text { Strong } \\
\text { positive }\end{array}$ \\
\hline
\end{tabular}




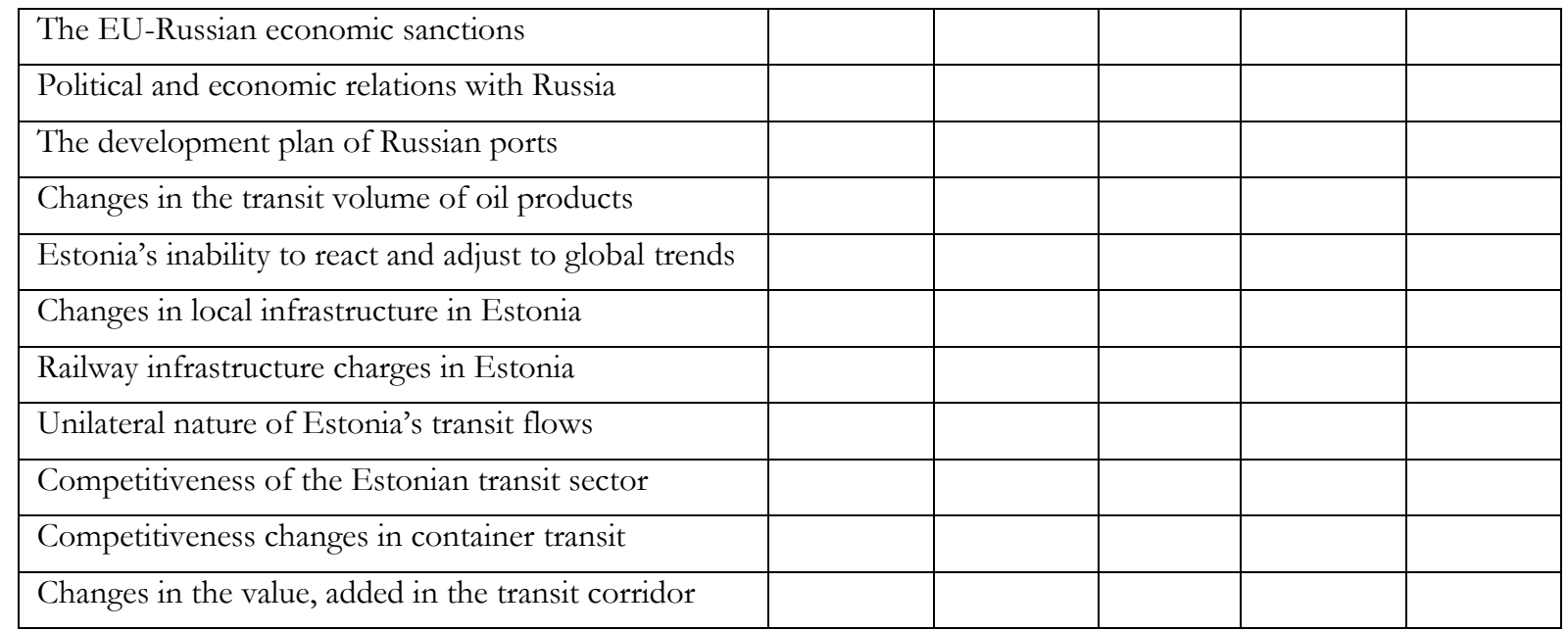

2c/3c/4c/5c: Entrepreneurs to respond to the question: Who are 3 main transit partners of your company in 2000-2006/in 2007-2008/in 2009-2011/from 2012 on? Experts to respond to the question: Which countries were 3 main transit partners of Estonia in 2000-2006/in 2007-2008/in 2009-2011/from 2012 on?

Part II of the survey: Assess the future outlook of the Estonian transit sector over the next decade

6a: How do you estimate what will be the state of transit sector and the transit flows in Estonia in 2019-2029?

\begin{tabular}{|c|c|c|c|c|}
\hline Very problematic & & Moderate concerns & & No problems at all \\
\hline 1 & 2 & 3 & 4 & 5 \\
\hline
\end{tabular}

6a(1): Please the entrepreneurs to respond to the question: How would you assess, is your company operating in the Estonian transit sector also in 2019-2029?

\begin{tabular}{|c|c|c|c|c|}
\hline Yes, certainly & $\begin{array}{c}\text { Yes, with a high } \\
\text { probability }\end{array}$ & I can't say & $\begin{array}{c}\text { No, with a high } \\
\text { probability }\end{array}$ & No, certainly not \\
\hline 1 & 2 & 3 & 4 & 5 \\
\hline
\end{tabular}

Please the entrepreneurs to respond to the question: Characterise the state and wellbeing of your company and the dynamics of the transit flows of your company in the Estonian transit sector in 2019-2029?

\begin{tabular}{|c|c|c|c|c|}
\hline Very problematic & & Moderate concerns & & No problems at all \\
\hline 1 & 2 & 3 & 4 & 5 \\
\hline
\end{tabular}

6b: What will be the impact of the following factors on the transit flows in Estonia in 2019-2029.

\begin{tabular}{|l|l|l|l|l|l|}
\hline & $\begin{array}{c}\text { Strong } \\
\text { negative }\end{array}$ & $\begin{array}{c}\text { Moderate } \\
\text { negative }\end{array}$ & $\begin{array}{c}\text { No } \\
\text { impact }\end{array}$ & $\begin{array}{c}\text { Moderate } \\
\text { positive }\end{array}$ & $\begin{array}{c}\text { Strong } \\
\text { positive }\end{array}$ \\
\hline The EU-Russian economic sanctions & & & & & \\
\hline Political and economic relations with Russia & & & & & \\
\hline The development plan of Russian ports & & & & & \\
\hline Changes in the transit volume of oil products & & & & & \\
\hline Estonia's inability to react and adjust to global trends & & & & & \\
\hline Changes in local infrastructure in Estonia & & & & & \\
\hline
\end{tabular}




\begin{tabular}{|l|l|l|l|l|l|}
\hline Railway infrastructure charges in Estonia & & & & & \\
\hline Unilateral nature of Estonia's transit flows & & & & & \\
\hline Competitiveness of the Estonian transit sector & & & & & \\
\hline Changes in container transit in Estonia & & & & & \\
\hline Changes in the value, added in the transit corridor & & & & & \\
\hline Rail Baltic project (track gauge of $1435 \mathrm{~mm})$ & & & & & \\
\hline Tunnel between Tallinn and Helsinki & & & & & \\
\hline
\end{tabular}

6c: Entrepreneurs to respond to the question: Who will be 3 main transit partners of your company in 2019-2029? Experts to respond to the question: Which will be 3 main transit partners of Estonia in 2019-2029?

6d: Assess the transit volumes and general trends in the Estonian transit sector in 2019-2029?

6e: What should be certainly done in Estonia to contribute to the development of the Estonian transit sector in 2019-2029 and what should be certainly avoided?

6f: What role should the state play in developing the activities in the Estonian transit and logistics sector? 